\title{
A nonconjugated naphthalene derivative of meso-tetra-(3-hydroxy)-phenyl-porphyrin as a sensitizer for photodynamic therapy
}

\author{
Abílio JFN Sobral ${ }^{*}$, Ana M Urbano², Pedro Silva ${ }^{1}$, Sofia M Fonseca ${ }^{1}$, Cláudia T Arranja', Hugh D Burrows ${ }^{1}$ \\ From 16th International Charles Heidelberger Symposium on Cancer Research \\ Coimbra, Portugal. 26-28 September 2010
}

Photodynamic Therapy (PDT) is a clinical procedure that is showing promising results in the treatment of certain types of cancer, including melanomas, oesophageal and retinal cancers [1-4]. The search for molecules suitable for use in PDT is a field of continuing interest. These molecules need to possess certain characteristics, including high affinity for tumour tissues and intense absorption in a region where biological tissues are relatively transparent. Porphyrin derivatives have become prime targets as sensitizers with potential to become good PDT agents, and have already been in use for over a decade in clinical PDT (ex: Foscan ${ }^{\circ}$ ). We report the synthesis and characterization of a meso-tetra-(3hydroxy)-phenyl-porphyrin ( $\mathrm{T}(\mathrm{OH}) \mathrm{PP})$ derivative to which a naphthyl isocyanate group was attached, giving the meso-tetra-(phenoxy-3-carbonyl-1-amino-naphthyl)porphyrin (T(NAF)PP (Figure 1).

The synthesized compound showed considerably enhanced photostability compared with the parent $\mathrm{T}$ $(\mathrm{OH}) \mathrm{PP}$ (photodegradation quantum yield $4.65 \times 10^{-4}$ ). The photosensitizer triplet state is normally considered to be essential for PDT, and to lead to the formation of cytotoxic oxygen species [5,6]. The lifetimes and quantum yields of the triplet state of T(NAF)PP were evaluated and presented typical values for this type of compounds. The quenching rate constant by molecular oxygen and singlet oxygen yield were also determined. The photodynamic effect in human carcinoma HT-29 cells was evaluated, and this novel porphyrin showed good properties as a sensitizer in photodynamic therapy

\footnotetext{
* Correspondence: asobral@ci.uc.pt

'Departmento de Química, Faculdade de Ciências e Tecnologia da

Universidade de Coimbra (FCTUC), Coimbra, Portugal

Full list of author information is available at the end of the article
}

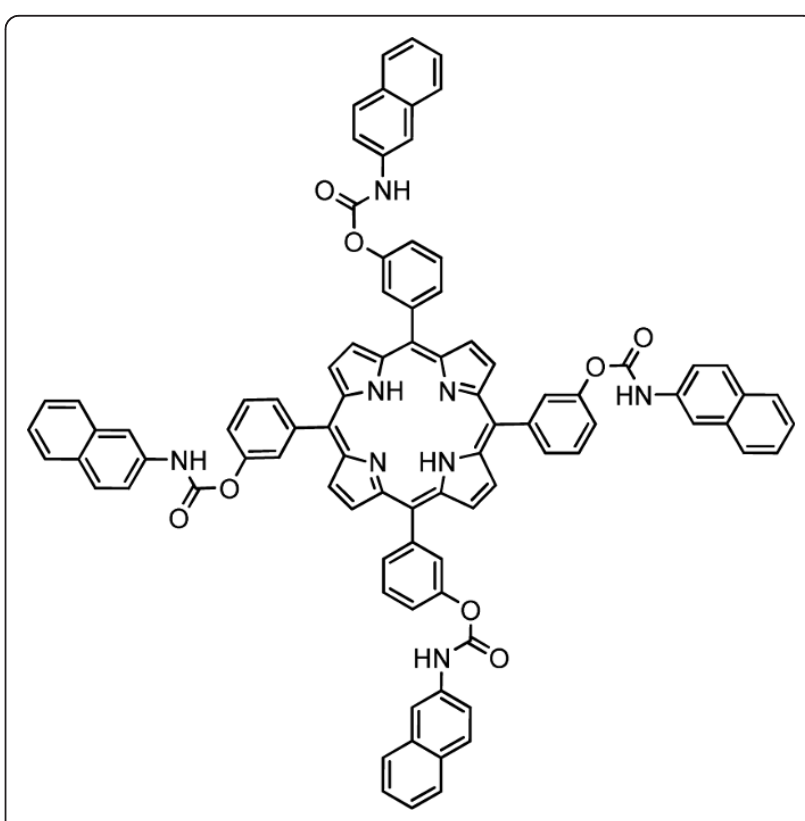

Figure 1

with an in vitro cytotoxicity $\mathrm{IC}_{50}$ value of $6.80 \mu \mathrm{g} \mathrm{mL} \mathrm{L}^{-1}$ for $24 \mathrm{~h}$ incubation.

\section{Author details}

'Departmento de Química, Faculdade de Ciências e Tecnologia da Universidade de Coimbra (FCTUC), Coimbra, Portugal. ${ }^{2}$ Unidade de Química Física Molecular and Departamento de Ciências da Vida, Faculdade de Ciências e Tecnologia da Universidade de Coimbra (FCTUC), Coimbra, Portugal.

\section{Published: 24 September 2010}

\section{References \\ . Epstein JH: Phototherapy and photochemotherapy. N Engl J Med 1990, 322:1149-1151.}


2. Claydon PE, Ackroyd R: Barrett's oesophagus and photodynamic therapy (PDT). Photodiagn Photodyn Ther 2004, 1:203-209.

3. Ohnishi Y, Yoshitomi T, Murata T, Sakamoto T, Ishibashi T: Electron microscopic study of monkey retina after photodynamic treatment. Med. Electron Microsc 2002, 35:46-52.

4. Maillard P, Loock B, Grierson DS, Laville I, Blais J, Doz F, Desjardins L, Carrez D, Guerquin-Kern J-L, Croisy A: In vitro phototoxicity of glycoconjugated porphyrins and chlorins in colorectal adenocarcinoma (HT29) and retinoblastoma (Y79) cell lines. Photodiagn Photodyn Ther 2007, 4:261-268.

5. Kalka K, Merk H, Mukhtar H: Photodynamic therapy in dermatology. J Am Acad Dermatol 2000, 42:389-416.

6. Pushpan SK, Venkatramant S, Anand VG, Sankar J, Parmeswaran D, Ganesan S, Chandrashekar TK: Porphyrin in photodynamic therapy - a search for ideal photosensitizers. Curr Med Chem Anticancer Agents 2002, 2:187-207.

doi:

Cite this article as: Sobral et al: A nonconjugated naphthalene

derivative of meso-tetra-(3-hydroxy)-phenyl-porphyrin as a sensitizer for photodynamic therapy. BMC Proceedings 2010 4(Suppl 2):P25.

\section{Submit your next manuscript to BioMed Central} and take full advantage of:

- Convenient online submission

- Thorough peer review

- No space constraints or color figure charges

- Immediate publication on acceptance

- Inclusion in PubMed, CAS, Scopus and Google Scholar

- Research which is freely available for redistribution

Submit your manuscript at www.biomedcentral.com/submit 